\title{
The Javanese Lunar Calendar's Effect on Indonesian Stock Returns
}

\author{
Robiyanto ${ }^{*}$ and Siti Puryandani \\ Faculty of Economics, Universitas Diponegoro, Indonesia
}

\begin{abstract}
It is very possible for an investor to take a decision based on superstitions and common beliefs. Actually, Indonesia has a specific calendar system called the Javanese lunar calendar. The Javanese calendar contains several special days because of their sacred characteristics such as "Kamis Wage" (Thursday Wage) and "Jum'at Kliwon" (Friday Kliwon). The day of Friday Kliwon is often considered to be the most frightening which is similar to Friday the Thirteenth in Western culture. This study tried to scrutinize the impact of those sacred days on Indonesian stock returns. By applying GARCH-M, the finding shows that the Javanese lunar calendar does not have any impact on the Indonesian stock returns, but does affect the investors' risk aversion level. This study has proven that, in terms of risk aversion, investors' behavior in Indonesia is influenced by superstition.
\end{abstract}

\begin{abstract}
Abstrak: Dalam pengambilan keputusan, seorang investor sangat mungkin berdasarkan takhayul dan keyakinan umum. Sebenarnya, Indonesia memiliki sistem kalender khusus yang disebut kalender lunar Jawa. Kalender Jawa berisi beberapa hari khusus karena kesakralannya seperti "Kamis Wage" dan "Jum'at Kliwon". Jumat Kliwon sering dianggap sebagai yang paling seram, sama dengan dengan Friday the 13th yang ada dalam budaya Barat. Penelitian ini berupaya mengkaji dampak dari hari-hari yang sacral tersebut terhadap return saham. Dengan menerapkan GARCH-M, temuan menunjukkan bahwa kalender lunar Jawa tidak memiliki dampak pada return saham Indonesia, tetapi berpengaruh pada tingkat penghindaran risiko investor. Penelitian ini telah membuktikan bahwa, dalam hal penghindaran risiko, perilaku investor di Indonesia dipengaruhi oleh takhayul.
\end{abstract}

Keywords: calendar anomaly; capital market efficiency; GARCH-M; Javanese lunar calendar; seasonality

JEL classification: G02; G10

* Corresponding author's e-mail: robiyanto76@gmail.com 


\section{Introduction}

A seasonal pattern (seasonality) is a type of calendar anomaly in financial markets which has attracted the attention of many researchers. Various studies have been conducted to explain this phenomenon and they include include research conducted by Lean and Tan (2010); Hmaied et al. (2006); Brockman and Chung (1999); Brockman and Michayluk (1998); Brooks (1997); Sias and Starks (1995); Dickinson and Peterson (1995); Lakonishok and Maberly (1990). They dealt with the Day of Week Effect and its impact on many capital markets in the world.

Related to this type of calendar anomaly, some researchers have tried to study the effect of investors' beliefs and superstitions on their behavior in financial markets. Kolb and Rodriguez (1987) found that the returns for Friday the Thirteenth were significantly lower that the returns for all the other Fridays over a long period in the NYSE. This evidence was the first documentation of the Friday the Thirteenth Effect. Chamberlain, Cheung, and Kwan (1991) supported the existence of the Friday the Thirteenth Effect by studying the return of S\&P 500 composite index. Many researches have also attempted to prove that the Friday the Thirteenth Effect still exists in the financial markets. Lucey (2000) obtained different results from his study in FTSE when he found that returns on Friday the Thirteenth was much higher than the other Fridays in FTSE. In his later study, Lucey (2001) also found the same results in eleven different financial markets.

Still related to calendar anomalies, some researchers have documented higher stock returns from November through April than from the rest of the year. According to Haggard and Witte (2010), this anomaly is known as the "Halloween effect". Lean (2011) found that the "Halloween effect" existed in some Asian stock markets. Non-secular calendar anomalies were also documented by Al-Ississ (2010) who found that the Muslim holy days of Ramadhan and Asyura tended to yield positive returns in seventeen different Muslim financial markets. Meanwhile, Frieder and Subrahmanyam (2004) found that the Jewish High Holy Days of Rosh Hashanah and St. Patrick's Day had a positive impact on stock returns, however, Jewish High Holy Days of Yom Kippur contributed negatively to stock returns in the United States.

These various pieces of empirical evidence indicate that the capital markets are not efficient in weak form. Those findings also indicate the urgency of theoretical approaches in addition to the assumption of efficient capital markets and investor rationality. In reality, many investors tend to use approaches or ways that can generate profits for them, regardless of whether they are rational or irrational. In fact, it is very possible for an investor to perform an action based on superstition and common beliefs. This has also been proposed by Liu (2010) who stated that cultural considerations and superstition could affect the process of behavior formation in financial markets as an expression of social psychology.

Another piece of research on seasonality was one entitled The Lunar Calendar Effect conducted by Liu (2010) which was based on the fact that the people with Oriental cultural backgrounds were likely to be influenced by superstitions and beliefs. The examples include seeking and avoiding the good and the bad days for every activity they are about to engage in, like weddings, funerals, and even business affairs. Thus, many investors with similar background will certainly consider those beliefs in their investment 
decisions. Liu (2010) concluded that the Chinese farmer calendar had an important role in predicting stock returns.

Actually, there are indigenous cultures in Indonesia which are similar to Oriental cultures. The Javanese lunar calendar system has close similarities to the Chinese farmer calendar with its lunar system. For instance, the Javanese community considers "Kamis Wage" (Thursday Wage) and "Jum'at Kliwon" (Friday Kliwon) to be very special days compared to the others based on their sacred characteristics. In addition, particularly for the Javanese community but also acknowledged by Indonesian people in general, Friday Kliwon is often considered as the most frightening day in a similar way to how Friday the Thirteenth is seen in Western culture. It is said that on Friday Kliwon night, ghosts and evil spirits gain their optimum power to kill humans. In fact, they believe that the ghosts will kill as many people as possible before the dawn comes. When the dawn comes, it is the time for God to punish them all and send them back to hell. This story is closely related to the tradition of Muslim people who worship on Fridays (called Good Friday), and it also evolved from local myth. Hence, Friday Kliwon is considered to be a dangerous day. Besides that day, Thursday Wage is also considered to be a dangerous day which may bring bad luck. Instead of being influenced by the myth, Muhaimin (1995) argued that the importance of Friday Kliwon for the Javanese community is mostly influenced by both Islamic tradition and Javanese tradition.

Unfortunately, research on the influence of the Javanese calendar on stock returns in Indonesia has not been conducted widely. According to the 2010 National Census carried out by Statistics Indonesia, there were 1,340 ethnic groups in this country and the Javanese were the largest one. They numbered just over 95,000,000 people or around 40 percent of the Indonesian population, i.e. almost 237,000,000 people. This indicates that research into finance affected by seasonality through the Javanese lunar calendar urgently needs to be conducted. Therefore, this study has tried to examine the influence of the days in the Javanese lunar calendar which were considered to be sacred on stock market returns at the Indonesia Stock Exchange.

\section{Behavioral Finance and Superstitions}

Behavioral finance is a relatively a new branch of financial research which stems from behavioral economics (Sowinski et al. 2011). Albaity and Rahman (2012) stated that behavioral finance had made advances in explaining the behavior of markets. It focuses on the irrational behavior of the individual in the economy. Several studies found that cultures and beliefs might affect investment decisions. Beckmann et al. (2007) found that in asset management there were country-specific differences that could hardly be explained by capital market theory but that were consistent with cultural influences on views and behaviors instead. This finding was supported by conclusion reached by Statman (2008) who concluded that the collective set of common experiences that people of the same culture share would influence their cognitive and emotional approaches to investing. Every different culture tends to have its own superstitions. For example, the number Thirteen is an unlucky number and Friday the Thirteenth is a bad day for the people of many countries with Judeo-Christian beliefs. While, the Oriental societies often consider that the number four is an unlucky number for when it is read, the pronunciation indicates the meaning of "dead." The number eight is a 
lucky number because the pronunciation indicates the meaning of "luck" (Brown and Mitchell 2004).

Kolb and Rodriguez (1987) are pioneers in superstition-related anomalies as they raised the issue of whether Friday the Thirteenth effect existed in capital markets. This study then motivated Chamberlain et al. (1991); Lucey $(2000,2001)$ to do the same research in different settings. However, those studies are barely suitable for generalizing to different countries with different cultures which have their own beliefs and do not adopt the Judeo-Christian beliefs. The same condition is also relevant to the study of the Chinese Lunar Calendar Effect. It is more appropriate for this effect to be observed in countries which are dominated by Chinese culture. Hence, superstition-related seasonalities must be scrutinized carefully with cultural background as a consideration.

\section{The Javanese Lunar Calendar System}

There are two categories of calendar system, namely theological calendar systems (e.g. Gregorian calendar system, Hijriah/Is- lamic calendar system, and Caka/Hindhu calendar system), and cultural calendar systems (e.g. Chinese lunar calendar system and Javanese lunar calendar system). The Javanese lunar calendar system is unique since it combines the Islamic, the Javanese Hindu-Buddha and a little mixture of Western cultural elements. There are some separate measurements of times in the Javanese Lunar Calendar. They are: a weekly cycle (consisting of seven days as found on the Gregorian calendar system such as Sunday, Monday Tuesday, Wednesday, Thursday, Friday and Saturday); the Pancawara cycle or Pasaran, which literally means market place (consisting of five days such as Legi (sweet), Pabing (bitter), Pon (partition), Wage (ugly or dirty) and Kliwon (love); the monthly cycle of Mangsa and Wulan; the yearly cycle called Tahun; and the eight year cycle called Windu. An academic study which accurately described the Javanese lunar calendar system was done by Damais (1955) who provided the calculation of those cycles. The simplest way to explain the combination of the weekly cycle and the Pancawara cycle, and also its jejer, is illustrated in Table 1. There are 35 days based on the weekly cycle and Pancawara cycle combination.

Table 1. The Jejer of Weekly Cycle (Gregorian Calendar) and Pancawara Cycle

\begin{tabular}{cccc}
\hline Days in Gregorian Calendar & Jejer & Days in Javanese Calendar & Jejer \\
\hline Friday & 1 & Kliwon & 1 \\
Saturday & 2 & Legi & 2 \\
Sunday & 3 & Pabing & 3 \\
Monday & 4 & Pon & 4 \\
Tuesday & 5 & Wage & 5 \\
Wednesday & 6 & & \\
Thursday & 7 & &
\end{tabular}


The term Pasaran is generated from the regular time for villagers to gather in the local market to meet socially and to buy and sell wares, products, foods, etc. Muhaimin (1995) has elaborated that Friday is the most important day of the week since it is put at the first ordinal standing (jejer). Meanwhile, Kliwon is considered also to be the most important day and is put at the first jejer. Friday Kliwon occurs only once in the thirty-five days and is considered to be the most significant moment for the first jejer of the seven-day week (Friday) and meets the first jejer of the five-day Pasaran week (Kliwon). The importance of Friday seems to be generated from the Islamic tradition that regards Friday as the master of the all days (Sayidul Ayyam) for conducting religious services. It remains unclear why Kliwon is considered to be significant though it must be due to the Javanese tradition and the evolvement of a local myth about Friday Kliwon. Similarly, Thursday Wage is also considered to be a sacred day since Thursday and Wage belong to the last jejer of both the seven-day week and the five-day Pasaran week respectively.

Through time, what was considered as myth in the past turned out into beliefs. People believe that ghosts and evil spirits really appear at those times. To make the legend even more terrifying, some people with strong beliefs in supernatural power will usually select those sacred days to practice their rituals. Many spiritual ceremonies are mostly held in Friday Kliwon (Muhaimin 1995; Damais 1955). Even some fanatical believers choose not to do anything within those days and prefer to postpone or cancel almost all the activities.

\section{Data}

The data which were analyzed in this study were the daily closing Jakarta Composite Index (JCI) in Indonesia Stock Exchange from July 1, 1997 to June 3, 2014 retrieved from Yahoo Finance. There were 4,107 trading days during that period which consisted of 162 days of Friday Kliwon, 641 days of non-Friday Kliwon, 163 days of Thursday Wage, and 648 days of non-Thursday Wage. The Wednesday Pon was also analysed because that day was the last day before those sacred days. During the research period there were 169 days of Wednesday Pon and 678 days of non-Wednesday Pon.

Stock market returns were calculated through the formula of:

Return $\mathrm{JCI}_{\mathrm{t}}=\left(\mathrm{JCI}_{\mathrm{t}}-\mathrm{JCI}_{\mathrm{t}-1}\right) / \mathrm{JCI}_{\mathrm{t}-1}$ $\mathrm{JCI}_{\mathrm{t}}=$ daily closing JCI on day $t$ $\mathrm{JCI}_{\mathrm{t}-1}=$ daily closing JCI on day $t-1$

\section{Methods}

Data analysis was performed through Generalized Autoregressive Conditional Heteroscedasticity (GARCH) developed by Bollerslev (1986). GARCH was used in this study for it was able to accommodate heteroscedasticity in the research model. The main consideration was a model with daily stock market returns as its variables tended to contain any heteroscedasticity or abnormal data as proven by Chion et al. (2008); Kamath, Chakornpipat, and Chatrath (1998); Corhay and Rad (1994); Richardson and Smith (1993). The GARCH model used in this study was GARCH-M developed by 
Engle et al. (1987) with final preferred model estimated parameterized the conditional mean as a function of $\log \left(\sigma^{2}\right)$. Nyberg (2010) stated that the general idea of the GARCHM model is that the conditional variance's coefficient in the conditional mean equation is interpreted as to measure the strength of risk aversion.

Thus, to test the influence of Thursday Wage, Friday Kliwon and Wednesday Pon on stock market returns, the models applied were:

Return $\mathrm{JCI}_{\mathrm{t}}=\beta$ Trading Day $+\lambda \sigma_{\mathrm{t}}^{2}+\varepsilon_{\mathrm{t}}$ with

$\varepsilon_{\mathrm{t}}=\Phi_{\mathrm{t}} \varepsilon_{\mathrm{t}-1}+\ldots+\Phi_{\mathrm{t}} \varepsilon_{\mathrm{t}-\mathrm{p}}+\eta_{\mathrm{t}}$

$\eta_{\mathrm{t}}=\varepsilon_{\mathrm{t}} \in_{\mathrm{t}}$

$\sigma_{\mathrm{t}}^{2}=\eta_{\mathrm{t}-1}^{2}+\ldots+\eta_{\mathrm{t}-\mathrm{p}}^{2}+\beta_{1} \sigma_{\mathrm{t}-1}^{2}+\ldots+\ldots \beta_{\mathrm{q}} \sigma_{\mathrm{t}-\mathrm{q}}^{2}$

and $\varepsilon$ t were independent and identical distributed $\mathrm{N}(0,1)$ and did not depend on the past condition of $\eta_{\mathrm{t}-\mathrm{p}}$.

Return JCI ${ }_{t}=$ Return daily JCI on Thursday or Friday or all trading day

Trading Day $=$ Dummy variable, 1 if it was Thursday Wage and 0 if not, or 1 if it was a Friday Kliwon

0 if not, or 1 if it was

Wednesday Pon and 0 if not.

Prior to the analysis of GARCH-M data stationarity test with the Augmented DickeyFuller Test and heteroscedasticity test, the ARCH-LM test were performed first.

\section{Results}

\section{Descriptive Statistics}

Descriptive statistics are presented in Table 2 and Table 3. The daily average return of the stock market on non-Thursday Wage was 0.060 percent. It was less than the daily average return of the stock market on Thursday Wage at 0.229 percent. The daily average return of the stock market on Thursday Wage was the highest when compared to the daily average return of the stock market on the other trading days and the other specific trading days studied. The risk of the stock market on Thursday Wage that was reflected in 1.581 percent standard deviation is the lowest when compared to standard deviation of non-Thursday Wage and the other trading days except other than non-Friday

Table 2. The JCI Return's Descriptive Statistics Based on Non-Wednesday Pon, Wednesday Pon, Non-Thursday Wage, Thursday Wage, Non-Friday Kliwon and Friday Kliwon

\begin{tabular}{lcccccc}
\hline Description & $\begin{array}{c}\text { Non- } \\
\text { Wednesday } \\
\text { Pon }\end{array}$ & $\begin{array}{c}\text { Wednesday } \\
\text { Pon } \\
\text { Wage }\end{array}$ & $\begin{array}{c}\text { Non- } \\
\text { Thursday }\end{array}$ & $\begin{array}{c}\text { Thursday } \\
\text { Wage } \\
\text { Kliwon }\end{array}$ & $\begin{array}{c}\text { Non- } \\
\text { Friday }\end{array}$ & $\begin{array}{c}\text { Friday } \\
\text { Kliwon }\end{array}$ \\
\hline Average Value & $0.161 \%$ & $-0.082 \%$ & $0.060 \%$ & $0.229 \%$ & $0.193 \%$ & $0.131 \%$ \\
Maximum Value & $7.922 \%$ & $4.989 \%$ & $8.408 \%$ & $7.586 \%$ & $11.284 \%$ & $5.821 \%$ \\
Minimum Value & $-10.375 \%$ & $-5.045 \%$ & $-11.955 \%$ & $-4.696 \%$ & $-7.639 \%$ & $-6.905 \%$ \\
Standard Deviation & $1.649 \%$ & $1.797 \%$ & $1.760 \%$ & $1.581 \%$ & $1.694 \%$ & $1.478 \%$ \\
$\mathrm{~N}$ & 678 & 169 & 648 & 163 & 641 & 162 \\
\hline
\end{tabular}


Table 3. The JCI Return's Descriptive Statistics Based on Trading Days

\begin{tabular}{lcccccc}
\hline Description & Monday & Tuesday & Wednesday & Thursday & Friday & All Day \\
\hline Average Value & $-0.137 \%$ & $0.057 \%$ & $0.112 \%$ & $0.094 \%$ & $0.181 \%$ & $0.061 \%$ \\
Maximum Value & $14.028 \%$ & $12.177 \%$ & $7.921 \%$ & $8.408 \%$ & $11.284 \%$ & $14.028 \%$ \\
Minimum Value & $-10.357 \%$ & $-8.874 \%$ & $-10.375 \%$ & $-11.955 \%$ & $-7.639 \%$ & $-11.955 \%$ \\
Standard Deviation & $1.860 \%$ & $1.650 \%$ & $1.682 \%$ & $1.726 \%$ & $1.652 \%$ & $1.714 \%$ \\
$\mathrm{~N}$ & 816 & 829 & 848 & 811 & 803 & 4107 \\
\hline
\end{tabular}

Kliwon. Since these findings show that Thursday Wage have a higher average daily return with lower standard deviation compared to that of non-Thursday Wage, so it seems that Thursday Wage which is considered as a sacred day since Thurday and Wage belong to the last jejer of both the seven-day week and the five-day Pasar week, and do not have any negative impact on return.

The daily average return of the stock market on non-Friday Kliwon was 0.193 percent and it was bigger than the daily average return of the stock market on Friday Kliwon at 0.131 percent. This study also found that the daily average return of the stock market on non-Friday Kliwon was the second highest when compared to daily average return on the other trading days and the other specific days studied. Meanwhile, the risk of the stock market on non-Friday Kliwon was reflected by the standard deviation of 1.694 percent. It was greater than the risk of the stock market on Friday Kliwon that was reflected by the standard deviation of 1.478 percent. The risk of the stock market on Friday Kliwon was the lowest when compared to daily average return on the other trading days and the other specific trading days studied. These findings are relatively similar to those for Thursday Wage. Friday and Kliwon belong to the first jejer of both the seven-day week and the five- day Pasar week, and do not have any negative impact on return.

In order to explore an additional explanation, this study add more day to be scrunitized, which is Rabu Pon (Wednesday Pon). This specific day need to be explored since the term of frightening (scary) for Indonesian people also was occured for a day/ night before sacred days (a day/night before Thurday Wage which is Wednesday pon and a day/night before Friday Kliwon which is Thursday Wage). They tend to takes a precautionary actions on a day before those sacred days occured consecutively.

The Wednesday Pon's daily average return was -0.082 percent, in contrast to the non-Wednesday Pon's daily average return was 0.161 percent which is higher. Surprisingly, the risk of stock market on Wednesday Pon that was reflected in 1.797 percent standard deviation is the highest when compared to standard deviation of Thursday Wage, Friday Kliwon and other trading days which were scrunitized specifically. These findings show that Wednesday Pon is the riskiest and investors tend to avoid it. This phenomenon is similar to the so called Monday Effect which tends to produce a negative daily average return with high risk, which was also found in this study. 
Table 4. Data Stationarity Test Results

\begin{tabular}{lccl}
\hline Description & t-Statistics & Probability & Conclusion \\
\hline Wednesday & $-55.710^{\mathrm{a}}$ & 0.000 & Stationary \\
Thursday & $-30.096^{\mathrm{a}}$ & 0.000 & Stationary \\
Friday & $-28.504^{\mathrm{a}}$ & 0.000 & Stationary \\
All Day & $-55.710^{\mathrm{a}}$ & 0.000 & Stationary \\
\hline
\end{tabular}

a Significant at $1 \%$

These descriptive statistics also lead to the conclusion that investors take precautionary actions by selling their stocks on Wednesday Pon in order to secure their portfolio since they are risk averse. Then they could take a buy position on the days after Wednesday Pon if there was no bad things that happened which affected the buy momentum. That is the possible reason why Thurday Wage's average daily returns and Friday Kliwon's average daily returns were positive and have lower standard deviation as risk measurement.

Based on the average value of weekdays' stocks market returns, it seems that the Day of the Week Effect, especially the Monday Effect and Friday Effect, still exists in Indonesia Stock Exchange since Monday's average stock market return was the lowest and Friday's average stock market return was the highest. So, it is not surprising that both Friday Kliwon and non-Friday Kliwon still produce positive stock market returns. Similarly, this also happened with Thursday though the stock market returns on this day were not the highest but when Thursday was divided into Thursday Wage and non-Thursday Wage, this study found that Thursday Wage produced the highest stock market returns.

In summary, the descriptive statistics show that Thursday Wage and Friday Kliwon, as sacred days, do not have a negative effect on average daily returns, but Wednesday Pon as a day before those sacred days, tend to produce negative daily average returns as a result of investors' precautionary actions.

\section{Data Stationarity Test Results}

Data stationarity test results through Augmented Dickey-Fuller are displayed in Table 4. Based on the table, it can be concluded that the requirement for data stationarity has been fulfilled.

\section{ARCH-LM Test Results}

ARCH-LM test results are shown in Table 5. Based on the table, it can be concluded that heteroscedasticity is detected. The GARCH model can be applied by accommodating the heteroscedasticity effect. These results also indicate that the previous day's (t-1) volatility has an impact on the returns in day t. So it is indispensable to include the variance equation on the model. In such instances, it needs to specify a ARCH- or GARCH-in-mean model and consider interactions of this sort in the conditional mean (level) equation. According to Bollerslev, Engle, and Nelson (1994), the ARCH-inmean (ARCH-M)/GARCH-M model adds a heteroscedasticity term to the mean equation. In brief, it is concluded that the LM diagnostic tests have revealed the robustness of GARCH-M model. 
Table 5. ARCH-LM Test Results

\begin{tabular}{lccc}
\hline Equation & F-Statistic & Probability & Conclusion \\
\hline $\begin{array}{l}\text { Wednesday Pon vs } \\
\text { Non-Wednesday Pon }\end{array}$ & $24.450^{a}$ & 0.000 & Heteroscedasticity was detected \\
$\begin{array}{l}\text { Thursday Wage vs } \\
\text { Non-Thursday Wage }\end{array}$ & $8.747^{\mathrm{a}}$ & 0.003 & Heteroscedasticity was detected \\
$\begin{array}{l}\text { Friday Kliwon vs } \\
\text { Non-Friday Kliwon }\end{array}$ & $67.207^{\mathrm{a}}$ & 0.000 & Heteroscedasticity was detected \\
$\begin{array}{l}\text { Wednesday Pon vs } \\
\text { All Day }\end{array}$ & $130.208^{\mathrm{a}}$ & 0.000 & Heteroscedasticity was detected \\
Thursday Wage vs All Day & $130.047^{\mathrm{a}}$ & 0.000 & Heteroscedasticity was detected \\
Friday Kliwon vs All Day & $130.724^{\mathrm{a}}$ & 0.000 & Heteroscedasticity was detected \\
\hline
\end{tabular}

a Significant at $1 \%$

\section{GARCH-M Analysis Results}

Based on the GARCH-M analysis results presented in Table 6 , it can be concluded that Thursday Wage did not have any influence on the daily returns the Indonesia Stock Exchange. The sign of regression coefficient showed that Thursday Wage tended to have positive impact on daily stock market returns in the Thursday Wage vs non-Thursday Wage equation. These findings were supported by evidence found in descriptive statistics which are shown in Table 2 and Table 3. Meanwhile, daily stock market returns on Thursday Wage were higher than non-Thursday Wage. The volatility depicted in the Thursday Wage vs non-Thursday Wage equation had a negative impact on stock returns on Thursday at 1 percent level of significance which means the higher volatility on Thursday leads to the lower returns. A different result was found for the Thursday Wage vs all trading days equation whereas the regression coefficient's sign was negative but it does not have a significant impact on stock returns. Meanwhile, the volatility coefficient had a negative impact on stock returns and significant at 1 percent significance level. It means that the higher the volatility, the lower the stock returns.

The regression coefficient's sign of dummy variables representing Friday Kliwon in the Friday Kliwon vs non-Friday Kliwon equation was negative yet did not have any significant impact on stock returns. This sign was supported by descriptive statistics as shown in Table 2, where the Friday Kliwon's average returns were lower than non-Friday Kliwon's average returns. Friday Kliwon also did not have any positive impact on daily stock market returns in Friday Kliwon vs all trading day. This finding was also supported by the evidence revealed in descriptive statistics. Volatility's regression coefficients in both equations contributed negative and sig- 
Table 6. GARCH-M Analysis Results

\begin{tabular}{lcccc}
\hline & & & \multicolumn{2}{c}{ Variance Equation Coefficient } \\
\cline { 5 - 6 } Equation & $\boldsymbol{\beta}$ & $\boldsymbol{\lambda}$ & $\boldsymbol{\eta}$ & $\boldsymbol{\beta}$ \\
\hline Wednesday Pon vs & -0.001450 & -0.000258 & 0.213408 & 0.667277 \\
Non-Wednesday Pon & {$[0.001130]$} & {$[0.000063]$} & {$[0.029607]$} & {$[0.041820]$} \\
& $(-1.283175)$ & $(-4.10860)^{\mathrm{a}}$ & $(7.207949)^{\mathrm{a}}$ & $(15.95612)^{\mathrm{a}}$ \\
Thursday Wage vs & 0.002004 & -0.000213 & -0.001080 & 1.001080 \\
Non-Thursday Wage & {$[0.001277]$} & {$[0.000061]$} & {$[0.000123]$} & {$[0.000123]$} \\
& $(1.568633)$ & $(-3.48851)^{\mathrm{a}}$ & $(-8.780918)^{\mathrm{a}}$ & $(8140.973)^{\mathrm{a}}$ \\
Friday Kliwon vs & -0.000829 & -0.000246 & 0.075586 & 0.924414 \\
Non-Friday Kliwon & {$[0.000805]$} & {$[0.000043]$} & {$[0.005681]$} & {$[0.005681]$} \\
& $(1.030128)$ & $(-5.62272)^{\mathrm{a}}$ & $(13.30495)^{\mathrm{a}}$ & $(162.7185)^{\mathrm{a}}$ \\
Wednesday Pon vs & 0.000003 & -0.000125 & 0.132900 & 0.852466 \\
All Day & {$[0.000808]$} & {$[0.000024]$} & {$[0.007261$} & {$[0.006834]$} \\
& $(0.004260)$ & $\left.(-5.29465)^{\mathrm{a}}\right]$ & $(18.30397)^{\mathrm{a}}$ & $(124.7413)^{\mathrm{a}}$ \\
Thursday Wage vs & -0.000294 & -0.000110 & 0.080808 & 0.919192 \\
All Trading Day & {$[0.000650]$} & {$[0.000016]$} & {$[0.002438]$} & {$[0.002438]$} \\
& $(0.452458)$ & $(-6.85804)^{\mathrm{a}}$ & $(33.14366)^{\mathrm{a}}$ & $(377.0079)^{\mathrm{a}}$ \\
Friday Klinvon vs & 0.001250 & -0.000103 & 0.080571 & 0.919429 \\
All Trading Day & {$[0.000717]$} & {$[0.0000163]$} & {$[0.002439]$} & {$[0.002439]$} \\
& $(1.743615)$ & $(-6.32139)^{\mathrm{a}}$ & $(33.03506)^{\mathrm{a}}$ & $(376.9787)^{\mathrm{a}}$ \\
\hline
\end{tabular}

Numbers in the brackets are standard errors

Numbers in the parentheses are z-Statistics

a Significant at $1 \%$

nificant impacts on stock returns at 1 percent level of significance, which means the higher volatility leads to the lower stock returns.

Meanwhile by elaborating the conditional variance included in the conditional mean equation, this study found that there is higher and significant risk aversion on the sacred days studied at 1 percent significance level. The strength of risk aversion on Friday Kliwon is higher than non-Friday Kliwon, and this condition also applied to Thursday Wage and even to Wednesday Pon as the day before those sacred days.
The strength of risk aversion on Wednesday Pon is the highest (-0.000258), since investors tend to take precautionary actions before those sacred days, followed by the strength of risk version on Friday Kliwon (-0.000246) and Thurday Wage (-0.000213).

\section{Conclusions and Recommendations}

Based on descriptive statistics, this study found a phenomenon which is similar to the Monday Effect on "Wednesday Pon" as the day before the sacred day being stud- 
ied with higher negative return and higher risk. This study concludes that "Thursday Wage" and "Friday Kliwon" do not have any significant impact on daily stock market returns. The same finding also applies to "Wednesday Pon" as the day before those sacred days. Interestingly, this study found significant risk aversion strength on those days and the strength of risk aversion on "Wednesday Pon" as the last day to take precautionary actions is at its highest, followed by "Friday Kliwon" and "Thurday Kliwon".

These findings show us that the Javanese lunar calendar effect doesn't exist in the Indonesia Stock Exchange but the investors' level of risk aversion is affected by it. Hence, in terms of risk aversion, the behavior of many investors is also influenced by superstition based on local culture.

\section{Limitations and Future Research Agenda}

This study focused only on Thursday Wage and Friday Kliwon as being the most sa- cred in Javanese culture, and Wednesday Pon as the day before those days; meanwhile there are the other remaining twenty two trading days according to the Lunar Javanese Calendar, therefore, it is recommended future that research investigates the influence of the Javanese calendar system on those remaining trading days. The application of a sophisticated approach is also welcome since this study was pioneering in this subject. It is also recommended that future research studies the month based on Javanese calendar system due to the existence of local beliefs and wisdom, such as the Month of Mubarram which is considered more sacred than other months.

Finally, since different cultures tend to have different superstitions and beliefs, the future research should explore whether other dominant, country-specific differences in superstitions and beliefs found in other parts of the world may affect investor's behavior in financial markets.

\section{References}

Al-Ississ, M. 2010. The impact of religious experience on financial markets. Working Paper.

Albaity, M., and R. Mahfuz. 2012. Behavioural finance and Malaysian culture. International Business Research 5 (11): 65-76.

Beckmann, D., L. Menkhoff, and M. Suto. 2007. "Does Culture Influence Assets Managers' Views and Behavior.” Journal of Economic Behavior \& Organization 67 (3-4):624-643.

Bollerslev, T. 1986. Generalized autoregressive conditional heteroscedasticity. Journal of Econometrics 31: 307-327.

Bollerslev, T., R. F. Engle, and D. B. Nelson. 1994. ARCH models. In R. F. Engle and D. L. McFaedden (edt.), Handbook of Econometrics. Elsevier Science B.V.

Brockman, P., and D. Y. Chung. 1999. Cross-listing and firm liquidity on the stock exchange of Hongkong. Managerial Finance 25 (1): 64-88.

Brockman, P., and D. Michayluk. 1998. Individual versus institutional investors and the weekend effect. Journal of Economics and Finance 22 (1): 71-85. 
Brooks, R. M. 1997. The individual investor and the weekend effect: A reexamination with intraday data. Quarterly Review of Economics and Finance 37 (7): 725-737.

Brown, P., and J. Mitchell. 2004. Culture and stock price clustering: Evidence from the Peoples' Republic of China. Working Paper.

Chamberlain, T. W., C. S. Cheung, and C. C. Y. Kwan. 1991. The Friday the Thirteenth effect: Myth or reality? Quarterly Journal of Business and Economics 30 (2): 111-117.

Chion, S. J., C. Veliz, and N. Carlos. 2008. On the normality of stock return distributions: Latin American markets 2000-2007. Journal of CENTRUM Cathedra 1 (2): 90-108.

Corhay, A., and A. T. Rad. 1994. Statistical properties of daily stock returns: Evidence from European Stock Markets. Journal of Business Finance and Accounting 21 (2): 271-282.

Damais, L-C. 1955. Études d'epigraphie Indonésienne IV. Bulletin de l'Ecole Française d'Extrême-Orient 47 (1): 7-190.

Dickinson, A., and D. R. Peterson. 1995. Expectations of weekend and turn-of-the-month mean return shifts implicit in index call option prices. Journal Of Financial and Strategic Decisions 8 (3): 69-76.

Engle, R. F., D. M. Lilien, and R. P. Robins. 1987. Estimating time varying risk premia in the term structure: The Arch-M model. Econometrica 55 (2): 391-407.

Frieder, L., and A. Subrahmanyam. 2004. Nonsecular regularities in returns and volume. Financial Analysts Journal 60 (4): 29-34.

Haggard, K. S., and H. D. Witte. 2010. The halloween effect: Trick or treat? International Review of Financial Analysis 19 (5): 379-387.

Hmaied, D. M., O. B. Sioud, and A. Grar. 2006. Intradaily and weekly patterns of bid-ask spreads, trading volume and volatility on the Tunisian Stock Exchange. Banque and Marchés 84 (September-October): 35-44.

Kamath, R. R., R. Chakornpipat, and A. Chatrath. 1998. Return distributions and the day-of-the-week effects in the Stock Exchange of Thailand. Journal of Economics and Finance 22 (2-3): 97-106.

Kolb, R. W., and R. J. Rodriguez. 1987. Friday the thirteenth: 'Part VII'—a note. Journal of Finance 42 (5): 1385-1387.

Lakonishok, J., and E. Maberly. 1990. The weekend effect: Trading pattern of individual and institutional investors. Journal of Finance 45 (1): 231-224.

Lean, H. H. 2011. The halloween puzzle in selected Asian Stock Markets. International Journal of Economics and Management 5 (1): 216-225.

Lean, H. H., and V. K. Min Tan. 2010. Existence of the day of the week effect in FTSE Bursa Malaysia. Jurnal Pengurusan 31: 3-11.

Liu, W. 2010. Lunar calendar effect: Evidence of the chinese farmer's calendar on the equity markets in East Asia. Working Paper.

Lucey, B. M. 2000. Friday the 13th and the philosophical basis of financial economics. Journal of Economics and Finance 24 (3): 294-301.

Lucey, B. M. 2001. Friday the 13th: International evidence. Applied Economics Letters 8 (9): 577-579.

Muhaimin, Abd. G. 1995. The Islamic Traditions of Cirebon:Ibadat and Adat Among Javanese Muslims. Canberra: ANU E Press. 
Nyberg, H. 2010. "QR-GARCH-M model for risk-return tradeoff in U.S. stock returns and business cycles. Discussion Papers (294). Helsinki Center of Economic Research.

Richardson, M., and T. Smith. 1993. A test for multivariate normality in stock returns. Journal of Business 66 (2): 295-321.

Sias, R. W., and L. T. Starks. 1995. The day-of-the-week anomaly: The role of institutional investors. Financial Analysts Journal (May/June): 58-67.

Sowinski, M., O. Schnusenberg, and S. Materne. 2011. Sprechen sie bias? An investigation of cultural differences in behavioral finance biases between germany and the United States. Journal of Behavioral Studies in Business 3 (4): 53-76.

Statman, M. 2008. Countries and culture in behavioral finance. CFA Institute Conference Proceedings Quarterly (September): 38-44. 